\title{
Controle de convencionalidade da nova lei de migração: uma observação acerca da questão dos refugiados no Brasil
}

\author{
Conventionality control of the new migration law: \\ a note about the refugee issue in Brazil
}

Maria Angélica Chichera

Pontifícia Universidade Católica de São Paulo - PUC/SP

RiCARDO GLASENAPP

Pontifícia Universidade Católica de São Paulo - PUC/SP

RESUMO O Direito Internacional estimula o diálogo entre as decisões internas e as diretrizes internacionais, o que impulsiona a atuação conjunta de vários Estados, ocorrendo a internacionalização do direito. No Brasil há tratamento especial para os tratados internacionais de direitos humanos, uma vez que a Emenda Constitucional ${ }^{\circ}$. 45, de 8 de dezembro de 2004, lhe conferiu a hierarquia de norma constitucional, passando, desse modo, a integrar o bloco de constitucionalidade. O presente artigo analisará acerca da convencionalidade da Nova Lei de Migração - Lei $\mathrm{n}^{\circ}$. 13.445/2017, especialmente no que diz respeito à questão dos refugiados, com o objetivo de observar a congruência normativa hierárquica existente entre a referida lei e os tratados internacionais de Direitos Humanos já ratificados pelo Brasil. Por se tratar de um estudo descritivo e exploratório, será realizado com base na pesquisa bibliográfica e histórica, utilizando o método dedutivo.

Palavras-chave: Controle de Convencionalidade. Direitos Humanos. Nova Lei de Migração. Refugiados. Tratados Internacionais de Direitos Humanos.

ABSTRACT International law encourages dialogue between domestic decisions and international guidelines, which drives the joint action of several states, leading to the internationalization of law. In Brazil, there is special treatment for international human rights treaties, since Constitutional Amendment No. 45, of December 8, 2004, gave it the hierarchy of constitutional norm, thus becoming part of the constitutional bloc. This article will analyze about the conventionality of the New Migration Law - Law No. 13.445 / 2017, especially with regard to the refugee issue, in order to observe the normative congruence that exists before the normative hierarchy existing between that law and the treaties. Human Rights 
already ratified by Brazil. Because it is a descriptive and exploratory study, it will be conducted based on bibliographic and historical research, using the deductive method.

Keywords: Control of conventionality. Human Rights. New Migration Law. RefugEes. International Human Rights Treaties.

\section{INTRODUÇÃo}

Com o fim da Segunda Guerra Mundial, propiciou-se uma abertura na política imigratória. Nessa ocasião, a realidade imigratória sofreu alterações consideráveis, no tocante à implementação de uma política imigratória nacional, em que as autoridades brasileiras passaram a admitir a vinda de refugiados e deslocados de guerra, na condição de imigrantes.

As perseguições, os riscos, as ameaças e os desastres ambientais de efeitos globais são cada vez mais frequentes, ocasionando diversas situações jurídicas para pessoas, grupos e Estados afetados que ainda não foram devidamente enfrentadas pelo Direito no plano internacional e no plano interno.

Sendo assim, analisar-se-á, em um primeiro momento, a dignidade humana dos refugiados assegurada pela Constituição Federal como fundamento da República Federativa do Brasil, buscando-se identificar as bases para a construção de um sistema de proteção específico, para essa categoria emergente de refugiados, que reconheça formalmente um status jurídico para as pessoas que se encontram nessa condição, ocasião em que a discriminação de uma pessoa, pelo fato de pertencer a outra nação, fere os princípios enraizados em nossa Constituição Federal, que tem como fundamento a dignidade da pessoa humana.

A proteção à pessoa em situação de refúgio iniciou-se com a Convenção Relativa ao Estatuto dos Refugiados, concluída em 28 de julho de 1951, e adotada pela Conferência das Nações Unidas de Plenipotenciários sobre o Estatuto dos Refugiados e Apátridas, designada especialmente para redigir documento relativo ao status legal dos refugiados. A intenção foi alcançar uma categoria cada vez mais numerosa e as implicações práticas de uma possível revisão e ampliação do sistema que, por sua vez, enfrenta inúmeras dificuldades no seu funcionamento.

Ademais, outro ponto importante que será abordado, em um segundo momento, diz respeito à nova lei de migração que trouxe mudanças significativas no que concerne ao tratamento aos refugiados, sob o ponto de vista de possibilitar mecanismos institucionais que, de um lado, possam garantir uma efetiva proteção, e de outro, possam prevenir, antecipar, financiar e organizar os movimentos populacionais dessa natureza, com intuito de inserir as migrações dentro do contexto da preocupação com a segurança nacional como uma das dimensões da paz e da segurança internacional e da garantia de realização dos direitos humanos.

Para tanto, a Lei de Migração apresenta em seu bojo princípios e diretrizes estabelecidos em seu artigo $3^{\circ}$., em especial a universalidade, indivisibilidade e interdependência dos Direitos Humanos, bem como, o repúdio e prevenção à xenofobia, ao racismo e a qualquer forma de discriminação.

Assim, serão exploradas as limitações existentes no Direito Internacional Público, com ênfase em instrumentos internacionais relativos à proteção dos refugiados e dos direitos humanos. 
Na sequência, serão examinados os aspectos do controle de convencionalidade acerca da questão dos refugiados no Brasil diante da lei de migração, uma vez que desde a Emenda Constitucional $n^{\circ}$. 45/2004 foi promulgado o debate a respeito do conflito entre tratados internacionais e a lei interna voltou à temática do universo jurídico nacional.

Frente às considerações e aos aspectos expostos nas linhas precedentes, o presente artigo analisará acerca da convencionalidade da Nova Lei de Migração - Lei n ${ }^{\circ}$. 13.445/2017, especialmente no que diz respeito à questão dos refugiados, com o objetivo de observar a congruência normativa hierárquica existente entre a referida lei e os tratados internacionais de Direitos Humanos já ratificados pelo Brasil.

Por se tratar de um estudo descritivo e exploratório, será realizado com base na pesquisa bibliográfica e histórica, utilizando o método dedutivo.

\section{A dignidade humana dos ReFugiados}

A dignidade da pessoa humana foi positivada pela Constituição Federal de 1988 como fundamento da República Federativa do Brasil, nos termos do inciso III, do artigo $1^{\circ}$. da referida Constituição.

Assim, a dignidade da pessoa humana funciona concomitantemente para delinear direitos fundamentais e para coibir restrições excessivas. Desse modo, o princípio da dignidade da pessoa humana emerge na aplicabilidade de todos os demais princípios e direitos.

Nesse sentido, Ingo Wolfgang Sarlet ressalta que:

A Constituição de 1988 foi a primeira na história do constitucionalismo pátrio a prever um título próprio destinado aos princípios fundamentais, situado - em homenagem ao especial significado e função destes - na parte inaugural do texto, logo após o preâmbulo e antes dos direitos fundamentais. Mediante tal expediente, o Constituinte deixou transparecer de forma clara e inequívoca a sua intenção de outorgar aos princípios fundamentais a qualidade de normas embasadoras e informativas de toda a ordem constitucional, inclusive dos direitos fundamentais, que também integram aquilo que se pode denominar de núcleo essencial da Constituição material. Igualmente sem precedentes em nossa evolução constitucional foi o reconhecimento, no âmbito do direito positivo, do princípio fundamental da dignidade da pessoa humana (art. $1^{\circ}$., inc. III, da CF), que não foi objeto de previsão no direito anterior. Mesmo fora do âmbito dos princípios fundamentais, o valor da dignidade da pessoa humana foi objeto de previsão por parte do Constituinte, seja quando estabeleceu que a ordem econômica tem por fim assegurar a todos uma existência digna (art. 170, caput), seja quando, no âmbito da ordem social, fundou o planejamento familiar nos princípios da dignidade da pessoa humana e da paternidade responsável (art. 226, $\S 6^{\circ}$.), além de assegurar à criança e ao adolescente o direito à dignidade (art. 277, caput). Assim, ao menos neste final de século, o princípio da dignidade da pessoa humana mereceu a devida atenção na esfera do nosso direito constitucional (SARLET, INGO WOLFGANG, 2003, p. 104).

Dessa forma, a dignidade da pessoa humana, fundamento do Estado Democrático de Direito, exige observância máxima pelos Poderes Constituídos e assegura ao cidadão o mínimo de efetividade dos direitos fundamentais. 
Assim, o sentido de dignidade é reconhecido hoje na maioria dos textos constitucionais dos países democráticos, uma vez que o representa como direito inerente à condição humana, independentemente do ambiente, da época, dos valores e das condições, concebendo-se, desse modo, a dignidade, como parte da própria natureza humana e inerente do homem. Portanto, é da dignidade da pessoa humana que decorrem todos os demais princípios e direitos.

Dessa maneira, constata-se que a dignidade da pessoa humana tem em sua estrutura dois aspectos, sendo um negativo e outro positivo. O primeiro aspecto é negativo, pois significa a afirmação da integridade física e espiritual do homem como dimensão irrenunciável da sua individualidade autonomamente responsável, e o outro aspecto é positivo, uma vez que diz respeito à ampla possibilidade de desenvolvimento e autodeterminação.

Assim, a dignidade da pessoa humana concorre como limite e obrigação dos poderes estatais. Como limite, vale ressaltar que a dignidade gera efeitos fundamentais contra atos que a violem e exponham a grave ameaça. Como obrigação, a dignidade humana implica deveres concretos de tutela por parte dos órgãos estatais, no sentido de proteger a dignidade de todos, assegurando também, por meio de medidas positivas, o devido respeito e promoção (MAURER, BEATRICE et al., 2005).

Desse modo, a dignidade da pessoa humana é um atributo intrínseco da pessoa humana, irrenunciável e inalienável, ou seja, é elementar à condição humana, uma vez que esse valor é inerente à pessoa, em toda e qualquer circunstância, sendo de responsabilidade do Estado a proteção e a promoção de sua existência.

O Estado tem a função essencial de proteger a dignidade da pessoa humana e, sucessivamente, de promovê-la. Assim, o indivíduo ao encontrar-se em situação nociva à sua dignidade, terá meios de receber do Estado a proteção que lhe é devida, ou seja, o Estado deverá atuar como promotor da dignidade humana.

Corroborando com esse entendimento, Ingo Wolfgang Sarlet dispõe que "[...] o Estado existe em função da pessoa, e não o contrário, já que o ser humano constitui a finalidade precípua, e não meio da atividade estatal" (SARLET, INGO, 2011, p. 68).

Dessa forma, o Estado, como guardião dos valores fundamentais da sociedade, deve intervir e proteger a dignidade da pessoa humana. É sua função, e na hipótese em que se verificar a ausência estatal, o consequente imediato será a perda de seu fundamento de existência e validade.

Nesse sentido, vale destacar as palavras de Fabio Konder Comparato quanto à vigência dos Direitos Humanos, que afirma:

[...] que a vigência dos Direitos Humanos independe de sua declaração em constituições, leis e tratados internacionais, exatamente porque se está diante de exigências de respeito à dignidade humana, exercidas contra todos os poderes estabelecidos, oficiais ou não (COMPARATO, 2007, p. 227).

Ainda que saibamos que o respeito à dignidade humana já bastaria para o cumprimento dos Direitos Humanos, resta claro que, diante de toda a história da humanidade, fazem-se necessárias normas jurídicas protetivas aos Direitos Humanos para que estes sejam efetivamente observados. 
No que diz respeito à questão dos refugiados, não seria diferente. A proteção à pessoa em situação de refúgio iniciou-se com a Convenção Relativa ao Estatuto dos Refugiados, concluída em 28 de julho de 1951 e adotada pela Conferência das Nações Unidas de Plenipotenciários sobre o Estatuto dos Refugiados e Apátridas, designada especialmente para redigir documento relativo ao status legal dos refugiados (RAMOS, Op. Cit., 2017, p.171).

Nesse sentido salientam Luiz Ernani Araújo e Estefânia Eugenia Barrichello que:

O fenômeno dos conflitos relacionados com divisões étnicas e sociais, violações
de direitos humanos e políticas discriminatórias não é novo. Como já foi visto,
no decorrer da história da humanidade muitos tiveram que abandonar os seus
lares, cidades ou países, vítimas de circunstâncias que atingiam sua segurança,
integridade física e psicológica ou, ainda, seus direitos humanos fundamentais.
Trata-se de um fenômeno recorrente, assim como é recorrente a aspiração por
refúgio e segurança em outro local (ARAUJO e BARICHELL, 2015, p. 129).

O primeiro documento internacional a dedicar-se exclusivamente à condição genérica do refugiado, seus direitos e deveres, foi a Convenção relativa ao Estatuto dos Refugiados, datado de 1951, e seu Protocolo Anexo, datado de 1967, o qual consagrou o conceito de refugiado em um tratado.

Os refugiados são migrantes internacionais forçados, que cruzam as fronteiras nacionais de seus países de origem, em busca de proteção, uma vez que fogem de situações de violência, como conflitos internos, internacionais ou regionais, perseguições em decorrência de regimes políticos repressivos, entre outras violações de direitos humanos.

Entre outros fatores que levam às migrações de refugiados, pode-se citar as questões étnicas, culturais e religiosas, desigualdade socioeconômica, altos níveis de pobreza e miséria e, sobretudo, instabilidade política.

Assim, uma situação de violência originada por um conflito político pode acarretar outros tipos de problemas sociais e econômicos, de modo que os fluxos de refugiados podem apresentar causas que se tornam combinadas (LOESCHER, 1996).

Evidencia-se, desse modo, que os refugiados são considerados migrantes que merecem proteção internacional, uma vez que foram forçados a se deslocar em função das situações de violência vivenciadas em seus países de origem. Logo, a condição de refugiado carrega em si, portanto, as noções de transitoriedade, provisoriedade e temporalidade. Os refugiados se situam no limiar entre o país de origem e o país de destino.

Ao deslocar-se entre os dois universos, ocupam posição liminar, tanto em termos identitários, culturais e sociais, assentada na falta de pertencimento enquanto membros da comunidade receptora e nos vínculos introjetados por códigos partilhados com a comunidade de origem; quanto em termos jurídicos, ao deixar de exercitar, ao menos em caráter temporário, o status de cidadão no país de origem e portar o status de refugiado no país receptor (BAUMAN, 2005).

Dessa forma, verifica-se a necessidade não apenas de proteção, mas também de assistência diante da crise humanitária enfrentada internamente, desde que respeitados os limites colocados à admissão, materializados em critérios de seleção, bem como, ao tempo de permanência nos territórios do Estado receptor. 
Em tese, o estatuto de refugiado constitui uma condição jurídica provisória. Contudo, muitas vezes, esses fatores se arrastam por anos ou décadas, enquanto os refugiados buscam meios e estratégias para restabelecer suas vidas, construindo relações sociais e laços afetivos, constituindo, por vezes, famílias nos países de destino.

No Brasil, o processo de acolhimento e integração dos refugiados é realizado pelo ACNUR, pela sociedade civil e pelo governo brasileiro (CONARE). Todos os membros do CONARE e a sociedade civil são mandatários do ACNUR, órgão da ONU responsável pela proteção dos refugiados na esfera internacional, que repassa para as instituições migratórias nacionais as orientações e a verba destinadas a essa prática de proteção (SILVA e MORAES, 2016, p. 106).

A transitoriedade de refugiados gera impactos não apenas para os Estados, mas também para as relações internacionais, considerando que as migrações internacionais se dão entre Estados soberanos, organizados num sistema internacional. Esses deslocamentos operam a transferência de um indivíduo sob a jurisdição de um Estado para a de outro, o que acarreta mudança no pertencimento a uma comunidade política (ZOLGBERG, 1999).

Sendo assim, o processo de integração local poderá resultar na possibilidade de naturalização, após anos de permanência no país receptor, quando o indivíduo deixa de se enquadrar na categoria de refugiado, ocasião em que as chances de regresso ao seu país de origem ficam reduzidas.

\section{A nova LeI de Migração - LeI No . 13.445/2017}

Diante da promulgação da Emenda Constitucional no. 45/2004, a discussão sobre o conflito entre tratados internacionais de direitos humanos e a lei interna voltou à baila no universo jurídico nacional, especialmente quanto ao acréscimo ao artigo $5^{\circ}$. do $\S 3^{\circ}$., que afirma que "os tratados e convenções internacionais sobre direitos humanos que forem aprovados, em cada Casa do Congresso Nacional, em dois turnos, por três quintos dos votos dos respectivos membros, serão equivalentes às emendas constitucionais", que trouxe um reposicionamento dos tratados internacionais de direitos humanos no ordenamento jurídico pátrio, tanto aos anteriores à emenda constitucional como aos posteriores.

Desse modo, com fundamento nos tratados e convenções internacionais de Direitos Humanos, ratificados pelo Brasil, nosso ordenamento jurídico viu-se obrigado a criar normas que visam permitir a entrada e permanência do indivíduo em situação de refúgio, além de procedimentos de regularização do refugiado em solo brasileiro, o que permite que ele goze de direitos sem prejuízo de sua situação.

O ordenamento jurídico brasileiro contava com o Estatuto do Estrangeiro, Lei $n^{\circ}$. 6.815, de 19 de agosto de 1980, o qual consagrou a definição da situação jurídica do estrangeiro em solo brasileiro e a criação do Conselho Nacional de Imigração.

Todavia, em 24 de maio de 2017 o Congresso Nacional aprovou a nova Lei de Migração $n^{\circ}$. 13.445, em vigor a partir de 20 de novembro de 2017 (180 dias após sua publicação), que além de substituir o antigo Estatuto do Estrangeiro, estabelece direitos e deveres dos emigrantes, imigrantes, residentes fronteiriços, visitantes e apátridas. 
O Presidente da República sancionou a nova lei com uma série de vetos, mas de um modo geral, a nova ordem legal trouxe uma nova política migratória, mais atualizada, tendo em vista a crise humanitária e o fluxo migratório ocorrendo em muitos países.

Para fins de aplicação da Lei $n^{\circ}$. 13.445/2017, o $\S 1^{\circ}$. do artigo $1^{\circ}$. define o conceito de cada situação de estrangeiro:
I - (VETADO); II - imigrante: pessoa nacional de outro país ou apátrida que trabalha ou reside
e se estabelece temporária ou definitivamente no Brasil;
III - emigrante: brasileiro que se estabelece temporária ou definitivamente no exterior;
IV - residente fronteiriço: pessoa nacional de país limítrofe ou apátrida que conserva a sua residência habitual em município fronteiriço de país vizinho;
$\mathrm{V}$ - visitante: pessoa nacional de outro país ou apátrida que vem ao Brasil para estadas de curta duração, sem pretensão de se estabelecer temporária ou defini- tivamente no território nacional;
VI - apátrida: pessoa que não seja considerada como nacional por nenhum Es- tado, segundo a sua legislação, nos termos da Convenção sobre o Estatuto dos Apátridas, de 1954, promulgada pelo Decreto ${ }^{\circ}$. 4.246, de 22 de maio de 2002, ou assim reconhecida pelo Estado brasileiro (Lei no ${ }^{\circ}$ 13.445/2017).

A nova Lei de Migração apresenta em seu bojo princípios e diretrizes estabelecidos em seu artigo $3^{\circ}$., em especial a universalidade, indivisibilidade e interdependência dos Direitos Humanos, bem como, o repúdio e prevenção à xenofobia, ao racismo e a qualquer forma de discriminação.

Ademais, está acrescido como princípio o acolhimento humanitário, igualdade de tratamento, inclusão social e laboral, promoção do reconhecimento acadêmico e do exercício profissional no Brasil, bem como, outras proteções inerentes a todos os estrangeiros residentes ou visitantes do Brasil, repúdio a práticas de expulsão ou de deportação coletivas, a promoção de entrada e de regularização documental, entre outras.

Importante mencionar que o inciso III do artigo $3^{\circ}$. põe fim à criminalização da migração, dessa forma, o migrante que entrar irregularmente no país não sofrerá sanções penais, contudo, não estará livre de outras sanções administrativas impostas pelas medidas de retirada compulsória, da repatriação, da deportação, da expulsão, estabelecidas nos artigos 46 a 62 .

$\mathrm{O}$ artigo $4^{\circ}$. dispõe que é garantido ao migrante, em território nacional, a inviolabilidade do direito à vida, à liberdade, à segurança e à propriedade, à saúde, à previdência social, à educação, à igualdade que são assegurados aos brasileiros, entre outros tipificados em seus incisos I a XVI.

Embora no texto original, o $\S 2^{\circ}$. do artigo $4^{\circ}$. previa a possibilidade do ingresso do imigrante a cargo, emprego e função pública, mas tal previsão foi vetada. ${ }^{1}$ Referidos dis-

\footnotetext{
1 Razões do veto: "Os dispositivos possibilitariam o exercício do cargo, emprego ou função pública por estrangeiro não residente, em afronta à Constituição e ao interesse nacional. Além disso, trata em diploma relativo ao tema migratório de matéria reservada à regulação de provimento de cargo público, cuja iniciativa é privativa do Presidente da República, a teor do artigo 61, $\S 1^{\circ}$., II, 'c', da Constituição. Ademais, reserva a edital de concurso a definição, concessão ou restrição de direitos, o que se configura inadequado à sua função de apenas direcionar a fiel execução da lei para acesso a carreiras públicas".
} 
positivos têm a finalidade de combater a discriminação de pessoas que vierem de outros países, vítimas de uma guerra civil, perseguições ou em busca de uma vida melhor que, ao chegarem ao Brasil, encontravam dificuldade para se instalar e conseguir o visto temporário. Por essa razão, era muito burocrática a contratação de estrangeiros para trabalhos.

Entre as inovações trazidas pela Nova Lei de Migração, destaca-se a possibilidade de concessão do visto temporário para outras finalidades, não trazidas pelo antigo estatuto, estabelecido no artigo 14, seguindo as hipóteses de seus incisos I a III, em especial, o inciso I, alínea "c", o qual diz que poderá ser concedido o Visto Temporário Humanitário que tenha como finalidade a "acolhida humanitária", e o conceito foi redigido no $\S 3^{\circ}$. do mesmo artigo, que dispõe:

O visto temporário para acolhida humanitária poderá ser concedido ao apátrida ou ao nacional de qualquer país em situação de grave ou iminente instabilidade institucional, de conflito armado, de calamidade de grande proporção, de desastre ambiental ou de grave violação de Direitos Humanos ou de direito internacional humanitário, ou em outras hipóteses, na forma de regulamento.

Ainda dispõe sobre a Condição Jurídica do Migrante e do Visitante em seu Capítulo III, definindo regras específicas ao Residente Fronteiriço; da Proteção ao Apátrida e da Redução da Apátrida; do Asilado; bem como dispõe também sobre a autorização de Residência, da qual deverá se enquadrar nas hipóteses do artigo 30.

Organiza também regras de entrada e saída do território nacional (arts. 38 a 43), bem como, dispõe sobre o impedimento de ingresso do estrangeiro, a fim de controlar a ordem pública e garantir a segurança nacional, conforme hipóteses de impedimento previstas no artigo 45 da Lei $n^{\circ}$. 13.445/2017:

I - anteriormente expulsa do País, enquanto os efeitos da expulsão vigorarem;

II - condenada ou respondendo a processo por ato de terrorismo ou por crime de genocídio, crime contra a humanidade, crime de guerra ou crime de agressão, nos termos definidos pelo Estatuto de Roma do Tribunal Penal Internacional, de 1998, promulgado pelo Decreto no 4.388, de 25 de setembro de 2002; III - condenada ou respondendo a processo em outro país por crime doloso passível de extradição segundo a lei brasileira;

IV - que tenha o nome incluído em lista de restrições por ordem judicial ou por compromisso assumido pelo Brasil perante organismo internacional;

$\mathrm{V}$ - que apresente documento de viagem que:

a) não seja válido para o Brasil;

b) esteja com o prazo de validade vencido; ou

c) esteja com rasura ou indício de falsificação;

VI - que não apresente documento de viagem ou documento de identidade, quando admitido;

VII - cuja razão da viagem não seja condizente com o visto ou com o motivo alegado para a isenção de visto;

VIII - que tenha, comprovadamente, fraudado documentação ou prestado informação falsa por ocasião da solicitação de visto; ou

IX - que tenha praticado ato contrário aos princípios e objetivos dispostos na Constituição Federal (Lei nº. 13.445/2017). 
Vale ressaltar que o parágrafo único do mesmo artigo aduz que "Ninguém será impedido de ingressar no País por motivo de raça, religião, nacionalidade, pertinência a grupo social ou opinião política".

Por fim, o artigo 121 dispõe que "Na aplicação desta Lei, devem ser observadas as disposições da Lei $n^{\circ}$. 9.474, de 22 de julho de 1997, nas situações que envolvam refugiados e solicitantes de refúgio", de modo que não haja conflito de Leis.

Após Consulta Pública sobre a Regulamentação da Lei no . 13.445/17, o Governo Federal promulgou Decreto Presidencial n. 9.199, de 20 de novembro de 2017, que regulamenta a Lei de Migração.

O Decreto criou um capítulo dirigido ao refúgio, previsto nos artigos 119 ao 122 , o qual estabelece que o solicitante de reconhecimento da condição de refugiado fará jus à autorização provisória de residência, até decisão final de seu pedido, bem como, será expedido a Carteira de Trabalho Provisória; Cadastro de Pessoa Física e poderá ainda abrir conta bancária em instituição financeira supervisionada pelo Banco Central do Brasil.

Assegura, ainda, que o procedimento de solicitação de refúgio terá prioridade, caso exista procedimento de medida de retirada compulsória em face do solicitante, conforme determina o artigo 122 do Regulamento.

Por fim, o Decreto tem por intuito regulamentar algumas lacunas que passaram na elaboração da Lei de Migração, tendo em vista que em inúmeros artigos consta a expressão "na forma de regulamento".

\section{Observações Sobre a CONVEncionalidade da nova Lei de Migração QUANTO À QUESTÃo DOS REFUGIADOS}

O controle de convencionalidade, assim como todas as demais espécies de controles hierárquicos normativos, tem por intuito verificar a compatibilidade vertical das leis nacionais diante de tratados internacionais de Direitos Humanos já ratificados.

Desde que a Emenda Constitucional n $n^{\circ}$. 45/2004 foi promulgada, o debate acerca do conflito entre tratados internacionais e leis internas voltou à temática no universo jurídico nacional. Esse debate foi gerado pela inovação no Direito que essa emenda constitucional trouxe. Entre tantas inovações constitucionais que essa emenda constitucional trouxe, destacamos o acréscimo ao artigo $5^{\circ}$. o $\S 3^{\circ}$., que determina que:

[...] os tratados e convenções internacionais sobre direitos humanos que forem aprovados, em cada Casa do Congresso Nacional, em dois turnos, por três quintos dos votos dos respectivos membros, serão equivalentes às emendas constitucionais.

O controle de convencionalidade no Brasil surge, portanto, com o advento da Emenda Constitucional $n^{\circ}$. 45/2004, promulgada em 30 de dezembro de 2004, especialmente com a inclusão do suprarreferido $\S 3^{\circ}$. do artigo $5^{\circ}$. Até a promulgação dessa emenda constitucional, os tratados e convenções internacionais, mesmo que versando sobre direitos humanos, entravam no direito interno com uma posição hierárquica de leis ordinárias. ${ }^{2}$

2 O procedimento constitucional adotado para que tratados e convenções internacionais passassem a vigorar no país era o mesmo da lei ordinária; qual seja, deveria ser, após a assinatura do agente plenipotenciário, aprovado pelo Congresso Nacional por meio de quórum de maioria simples, conforme disposto no artigo 47 da Constituição Federal e, posteriormente, ratificado por meio da promulgação de decreto presidencial. 
Acerca dessa hierarquia constitucional dos tratados internacionais de direitos humanos, Flávia Piovesan muito bem afirma que:

[...] ao revés, que conferir hierarquia constitucional aos tratados de direitos humanos, com a observância do princípio da prevalência da norma mais favorável, é interpretação que se situa em absoluta consonância com a ordem constitucional de 1988, bem como com sua racionalidade e principiologia. Trata-se de interpretação que está em harmonia com os valores prestigiados pelo sistema jurídico de 1988, em especial do valor da dignidade humana - que é o valor fundante do sistema constitucional. Insiste que a teoria da paridade entre o tratado internacional e a legislação não se aplica aos tratados internacionais de direitos humanos, tendo em vista que a Constituição de 1988 assegura a esta garantia de privilégio hierárquico, reconhecendo-lhes natureza de norma constitucional. Esse tratamento jurídico diferenciado, conferido pelo art. $5^{\circ} . \S 2^{\circ}$. da Carta de 1988, justifica-se na medida em que os tratados internacionais de direitos humanos apresentam um caráter especial, distinguindo-se dos tratados comuns. Enquanto estes buscam o equilíbrio e a reciprocidade de relações entre os Estados-partes, aqueles transcendem os meros compromissos recíprocos entre os Estados pactuantes. Os tratados de diretos humanos objetivam a salvaguarda dos direitos do ser humano, e não das prerrogativas do Estado (PIOVESAN, 2011, p. 211).

Dessa forma, inquestionável é a valorização trazida pela Emenda Constitucional $\mathrm{n}^{\circ}$. 45/2004 para os direitos humanos no Brasil. Além de elevar os tratados internacionais de direitos humanos ao status constitucional, vale lembrar que a criação do incidente de deslocamento de competência como forma de maior efetivação da proteção estatal dos direitos humanos também se deu por meio da referida emenda constitucional.

Assim, podemos admitir que os direitos humanos passaram por uma transformação significativa no ordenamento jurídico brasileiro com a Emenda Constitucional no ${ }^{\circ}$. 45/2004 e, naturalmente, toda a jurisprudência surgida em decorrência dela, restando clara a intenção estatal de trazer uma maior proteção às pessoas residentes no país. Uma vez demonstrada essa inovação jurídica no Brasil advinda com a instituição do $\S 3^{\circ}$. no artigo $5^{\circ}$. da Constituição Federal, e toda sua influência no ordenamento jurídico e jurisprudência decorrente, passaremos a observar o controle de convencionalidade.

André de Carvalho Ramos conceitua o controle de convencionalidade como a "análise da compatibilidade dos atos internos (comissivos ou omissivos) em face das normas internacionais" (RAMOS, 2015, p. 321).

Flavia Piovesan observa o controle de convencionalidade mais voltado ao Direito Internacional dos Direitos Humanos do que internamente, vez que afirma que:

...sempre que tratarmos do controle de convencionalidade e do diálogo entre jurisdição, observa-se alguns desafios para o ius commune latino-americano em matéria de direitos humanos; entre tais desafios a autora menciona: a) promover a ampla ratificação dos tratados internacionais de proteção dos direitos humanos da ONU - Organização das Nações Unidas e da OEA - Organização dos Estados Americanos; b) fortalecer a incorporação dos tratados de direitos humanos com um status privilegiado na ordem jurídica doméstica; c) fomentar 
uma cultura jurídica orientada pelo controle da convencionalidade; d) fomentar programa de capacitação para que os Poderes Legislativos, Executivo e Judiciário apliquem os parâmetros protetivos internacionais em matéria de direitos humanos; e) dinamizar o diálogo entre os sistemas regionais objetivando seu fortalecimento; f) aprimorar os mecanismos de implementação das decisões internacionais no âmbito interno; g) dinamizar o diálogo horizontal entre as jurisdições constitucionais. Assim, a autora observa claramente, como se depreende, a necessidade de fomento da cultura jurídica orientada pelo controle de convencionalidade das normas jurídicas; o que implica na observação da compatibilidade das leis e atos jurídicos nacionais com os tratados internacionais de direitos humanos (PIOVESAN, FLÁVIA, Temas de Direitos Humanos, 2012).

Nas palavras de Valério de Oliveira Mazzuoli, o controle de convencionalidade "trata-se de adaptar ou conformar os atos ou leis internas aos compromissos internacionais com reflexos práticos no plano do seu direito interno" (MAZZUOLI, 2013, p. 128).

Em outras palavras, diz-se que por meio do controle de convencionalidade é que se adapta, se coaduna, o ordenamento jurídico preexistente aos (novos) ditames jurídicos advindos por meio de tratados internacionais de direitos humanos, quer no nível constitucional quer no nível supralegal e infraconstitucional.

Mazzuoli propôs resolver a questão da convencionalidade das normas jurídicas por um interessante prisma: partindo do pressuposto que o Supremo Tribunal Federal já aceita de maneira pacífica a supralegalidade dos tratados internacionais de direitos humanos que dessa forma irradiam efeitos sobre todo o ordenamento jurídico, a fortiori pode-se sustentar que eles formam uma dupla barreira de compatibilidade, abaixo da Constituição Federal, mas acima de todo o restante da pirâmide jurídica. Para o autor, "toda produção legislativa fica condicionada não apenas ao chamado controle de constitucionalidade, cujo paradigma de controle é a Constituição; mas também a um segundo tipo de fiscalização, "complementar e coadjuvante (jamais subsidiário)", denominado por este como controle de convencionalidade vez que deriva das convenções internacionais, tendo como paradigma de controle os tratados internacionais. No entendimento do autor, o Supremo Tribunal Federal, em decisão histórica de 2008, ${ }^{3}$ afirmou competir aos juízes e Tribunais o dever constitucional "de atuar na defesa incondicional e na garantia real das liberdades fundamentais da pessoa humana", trazendo uma efetividade aos direitos previstos em tratados internacionais; havendo aqui uma missão social e politicamente mais importante e sensível que se impõe a eles (MAZZUOLI, 2013, p. 209).

Assim, pode-se afirmar que o controle de convencionalidade vem a ser, de forma sucinta, a comparação no que diz respeito à compatibilidade vertical de leis e atos normativos às normas jurídicas de direitos humanos, que se encontram tanto em nível constitucional como em nível supralegal e infraconstitucional.

Até 30 de dezembro de 2004, data da promulgação da Emenda Constitucional $\mathrm{n}^{\circ}$. 45/2004, os tratados e convenções internacionais, mesmo que versando sobre direitos hu-

3 Essa tese da supralegalidade e infraconstitucionalidade dos tratados internacionais de direitos humanos surgiu no julgamento do RHC n $\mathrm{n}^{\circ}$. 79.785-RJ, ocorrido em 29 de março de 2000, pelo voto do Relator Ministro Sepúlveda Pertence, que aventou pela primeira vez a possibilidade de os tratados internacionais de direitos humanos serem documentos supralegais. 
manos, adentravam ao direito interno com uma posição hierárquica equivalente às leis ordinárias; logo, a tramitação adotada para que tratados e convenções internacionais passassem a vigorar no país era o mesmo da lei ordinária, qual seja, deveria, após a assinatura do agente plenipotenciário, em regra o Presidente da República, ser aprovado pelo Congresso Nacional por meio de quórum de maioria absoluta, conforme artigo 47 da Constituição Federal, e, posteriormente, ratificado por meio da promulgação de decreto presidencial. ${ }^{4}$

Analisando o disposto no $\S 3^{\circ}$. do artigo $5^{\circ}$. da Constituição Federal, que foi acrescido por meio da referida emenda, observa-se que os tratados internacionais que versarem sobre direitos humanos e que forem aprovados pelo Congresso Nacional pelo quórum especial das emendas constitucionais se equivalerão às emendas constitucionais; enquanto que os demais tratados internacionais, que versarem sobre os demais assuntos permanecerão a adentrar no ordenamento jurídico interno brasileiro por meio da regra tradicional já existente anteriormente à Emenda Constitucional n ${ }^{\circ} .45 / 2004$.

Todavia, o disposto neste parágrafo $3^{\circ}$. do artigo $5^{\circ}$. fez surgir no ordenamento jurídico nacional uma dupla previsão dos tratados internacionais de direitos humanos: uma no nível constitucional, aqueles que forem aprovados após a Emenda Constitucional $n^{\circ} .45 / 2004$, e outra no nível de supralegalidade e infraconstitucionalidade, aqueles que já foram ratificados antes da referida emenda constitucional.

Decorre da necessidade de visualização da compatibilidade das normas legais com as normas previstas em tratados internacionais de direitos humanos entendidas como supralegais e infraconstitucionais, como bem decidiu, em 2008, o Supremo Tribunal Federal em decisão proferida no Recurso Extraordinário 466.343, da relatoria do Min. Gilmar Mendes, no qual ficou definida a atual intepretação do Supremo Tribunal Federal acerca da hierarquia das normas jurídicas no direito nacional.

Decidiu o Supremo Tribunal Federal que os tratados internacionais que versem sobre matéria relacionada a Direitos Humanos têm natureza infraconstitucional e supralegal - à exceção dos tratados aprovados em dois turnos de votação por três quintos dos membros de cada uma das casas do Congresso Nacional, os quais, a teor do artigo $5^{\circ}$., $\S 3^{\circ}$., da Constituição Federal, os quais possuem status constitucional.

Portanto, há que se verificar a compatibilidade das normas jurídicas legais com as normas jurídicas estabelecidas em tratados internacionais de direitos humanos, uma vez que se observa uma hierarquia normativa destas em relação àquelas.

Dessa forma, ao analisar o controle de convencionalidade da nova Lei de Migração com a Convenção Relativa ao Estatuto dos Refugiados, datada de 1951, observa-se que a lei nacional apresenta em seu texto princípios e diretrizes, com destaque para a universalidade, indivisibilidade e interdependência dos Direitos Humanos, como também o repúdio e prevenção à xenofobia, ao racismo e a qualquer forma de discriminação, no mesmo sentido da norma jurídica internacional.

4 Cumpre destacar que no nosso ordenamento jurídico não há qualquer previsão normativa estabelecendo a necessidade do decreto presidencial ratificador do tratado internacional. Todavia, a doutrina entende que somente com tal decreto presidencial é que os efeitos de tratado ou convenção internacional começam a ser produzidos no direito interno. Trata-se, portanto, de uma tradição jurídica que data no Direito pátrio desde 1826; vez que expressa e taxativamente não há, e nem nunca houve, nenhum dispositivo constitucional exigindo tal decreto presidencial. 
Igualmente, está estabelecido na lei nacional como princípio norteador o acolhimento humanitário, igualdade de tratamento, inclusão social e laboral, promoção do reconhecimento acadêmico e do exercício profissional no Brasil, da mesma forma que outras proteções inerentes a todos os estrangeiros residentes ou visitantes do Brasil, repúdio a práticas de expulsão ou de deportação coletivas, a promoção de entrada e de regularização documental, entre outras; o que nos permite observar a convencionalidade da norma interna diante da Convenção Relativa ao Estatuto dos Refugiados.

Por fim, nota-se a convencionalidade da norma jurídica interna na garantia ao migrante, em território nacional, da inviolabilidade do direito à vida, à liberdade, à segurança e à propriedade, à saúde, à previdência social, à educação, à igualdade que são assegurados aos brasileiros; que não só confirmam a aplicação em nível legal da Constituição Federal como também quanto do tratado internacional de direitos humanos ora em destaque.

\section{CONSIDERAÇões FINAIS}

Diante do todo o exposto, conclui-se que a Nova Lei de Migração trouxe uma nova ordem jurídica à importante questão dos refugiados, de modo a trazer uma maior efetivação dos Direitos Humanos, já que, como observado, a mesma foi redigida com total respeito às normas jurídicas estabelecidas em tratados internacionais de direitos humanos.

A Nova Lei de Migração ao estabelecer suas normas jurídicas a fez com observação da dignidade humana dos refugiados, que está assegurada tanto na Constituição Federal como em um de seus fundamentos como também com observação à Convenção Relativa ao Estatuto dos Refugiados, como vimos. Além disso, o sistema de proteção específico para os refugiados foi idealizado tendo como fundamento a dignidade da pessoa humana.

Portanto, é de se louvar que, em tempos como os atuais, em que se observa graves violações dos Direitos Humanos por parte do Estado brasileiro, bem como, a existência de normas jurídicas incompatíveis hierarquicamente com as normas constitucionais e convencionais, tenhamos a publicação de uma importante nova lei que surge com total observação aos aspectos estabelecidos em tratados internacionais de direitos humanos, especialmente no que diz respeito à dignidade da pessoa humana.

\section{REFERÊNCIAS}

ACNUR. O Conceito de Pessoa Apátrida segundo o Direito Internacional. Reunião de especialistas organizada pelo escritório do Alto Comissariado das Nações Unidas para Refugiados, Prato, Itália, 27-28 de maio de 2010. Disponível em: <http://www.acnur.org/t3/ fileadmin/Documentos/portugues/BDL/O_Conceito_de_Pessoa_Apatrida_segundo_o_Direito_Internacional.pdf> Acesso em: 4 out. 2017.

Agência da ONU para Refugiados. Manual de Procedimentos e Critérios para Determinar a Condição de Refugiado. CONARE, ACNUR e Ministério da Justiça, 2013. Disponível em: <http://www.acnur.org/fileadmin/scripts/doc.php?file=fileadmin/Documentos/ 
portugues/Publicacoes/2013/Manual_de_procedimentos_e_criterios_para_a_determinacao_da_condicao_de_refugiado> Acesso em: 26/11/2017.

Agência da ONU para Refugiados. Direitos e Deveres dos Solicitantes de Refúgio e Refugiados no Brasil. Cartilha informativa em português, francês e espanhol. ACNUR, 2012.

Agência da ONU para Refugiados. Coletânea de Instrumentos de Proteção Nacional e Internacional de Refugiados e Apátridas. ACNUR. Disponível em: $<$ http://www.acnur. org/t3/fileadmin/Documentos/portugues/Publicacoes/2012/Lei_947_97_e_Coletanea_de Instrumentos_de_Protecao_Internacional_de_Refugiados_e_Apatridas.pdf $>$ Acesso em: 5 out. 2017.

Agência da ONU para Refugiados. Protegendo Refugiados no Brasil e no Mundo. ACNUR. Disponível em: $<$ http://www.acnur.org/fileadmin/Documentos/portugues/Publicacoes/2016/Cartilha_Protegendo_Refugiados_No_Brasil_e_no_Mundo.pdf $>$ Acesso em: 17 nov. 2017.

AGIER, MICHEL. Refugiados diante da nova ordem mundial. Tempo Social, revista de sociologia da USP, v. 18, n. 2.

ARAUJO, LUIZ ERNANI BONESSO DE; BARICHELLO, ESTEFÂNIA EUGENIA. Aspectos históricos da evolução e do reconhecimento internacional do status de refugiado. Revista do Direito da UNISC, Santa Cruz do Sul, v. 2, n. 46, p. 104-134, mai./ago. 2015 .

BARBOSA, LUCIANO P.; SAGRADO DA HORA, JOSÉ R. A polícia federal e a proteção

internacional dos refugiados. Brasília: ACNUR, 2007.

BARNETT, MICHAEL. Humanitarianism, Paternalism, and the UNHCR. In: BETTS, ALEXANDER; LOESCHER, GIL. (Org.). Refugees in International Relations. Oxford: Oxford University Press, 2010.

BARRETO, LUIZ PAULO TELES FERREIRA (Org.). Refúgio no Brasil: A proteção Brasileira aos Refugiados e seu Impacto nas Américas, 1. ed. Brasília, ACNUR, Ministério da Justiça, 2010.

BARRETO, LUIZ PAULO TELES FERREIRA (Org.). Das Diferenças entre os Institutos Jurídicos do Asilo e do Refúgio. Publicado em 14/09/2006. Disponível em: <http:// www.migrante.org.br/index.php/refugiados-as2/133-das-diferencas-entre-os-institutos-juridicos-do-asilo-e-do-refugio> Acesso em: 9 nov. 2017. 
BAUMAN, ZYGMUNT. Vidas desperdiçadas. Rio de Janeiro: Jorge Zahar, 2005.

BITTAR, EDUARDO C. B. e ALMEIDA, G. (Orgs.). Mini código de Direitos Humanos. Secretaria Especial dos Direitos Humanos, 2010, Brasília, 2010.

BOBBIO, NORBERTO. A Era dos Direitos. Nova Ed. Rio de Janeiro: Elsevier, 2004.

BRASIL. Decreto no . 9.199, de 21 de novembro de 2017. Regulamenta a Lei $\mathrm{n}^{\mathbf{0}}$. 13.445, de 24 de maio de 2017, que institui a Lei de Migração. Disponível em: <http:/www.planalto.gov.br/ccivil_03/_ato2015-2018/2017/decreto/D9199.htm> Acesso em: 21 nov. 2017.

BRASIL. Lei $\mathbf{n}^{\mathbf{0}} \mathbf{9 . 4 7 4}$, de 22 de julho de 1997. Define mecanismos para a implementação do Estatuto dos Refugiados de 1951, e determina outras providências. Disponível em: <http://www.planalto.gov.br/ccivil_03/leis/L9474.htm> Acesso em: 11 nov. 2017.

BRASIL. Lei n⿳0 13.445, de 24 de maio de 2017. Institui a Lei de Migração. Disponível em: <http://www.planalto.gov.br/ccivil_03/_ato2015-2018/2017/lei/L13445.htm> Acesso em: 12 nov. 2017.

BRASIL. Constituição da República Federativa do Brasil de 1988. Disponível em: < http:// www.planalto.gov.br/ccivil_03/constituicao/constituicao.htm>Acesso em: 14 out. 2020.

BRASIL. Emenda Constitucional nº 45, de 30 de dezembro de 2004. Disponível em: $<$ http://www.planalto.gov.br/ccivil_03/constituicao/emendas/emc/emc45.htm> Acesso em: 14 out. 2020 .

CANÇADO TRINDADE, ANTÔNIO A. (Org.). A Incorporação das Normas Internacionais de Proteção dos Direitos Humanos no Direito Brasileiro. San José, C. R.: IIDH, ACNUR, CIVC, CUE, 1996.

CANÇADO TRINDADE, ANTÔNIO AUGUSTO. A Proteção Internacional dos Direitos Humanos e o Brasil (1948-1997): as primeiras cinco décadas. Brasília: Ed. Unb, 2000, 2. ed.

CASTLES, STEPHEN; MILLER, MARK J. The age of migration. Basingstoke: Palgrave Macmillan, 2003.

COMPARATO, FABIO KONDER. AAfirmação Histórica dos Direitos Humanos, 5. ed. rev. e atual. São Paulo: Saraiva, 2007.

CONLEY, MARSHALL. The institutional framework of refugee law and political forces. In: MAHONEY, KATHLEEN; MAHONEY, PAUL (Org.). Human Rights in twenty-first century: a global challenge. Dordrecht: Kluwer Academic Publications, 1993. 
D’ÁVILA LOPES, ANA MARIA; VIANA, RAFAELA GOMES. A proteção das crianças refugiadas no Brasil por meio do controle de convencionalidade. Revista direitos e garantias fundamentais. Vitória, v. 17, n. 2, p. 81-106, jul./dez. 2016.

GOMES, EDUARDO BIACCHI; FLORES, PEDRO HENRIQUE BRUNKEN. Formulação de decisões administrativas em matéria de direitos humanos. Revista do Direito. Santa Cruz do Sul, v. 1, n. 57, p. 03-21, jan./abr. 2019.

JUBILUT, LILIANA LYRA. O Direito Internacional dos Refugiados e a sua Aplicação no Ordenamento Jurídico Brasileiro. São Paulo: Método 2007.

LAFER, CELSO. A internacionalização dos Direitos Humanos: O desafio do direito a ter direitos. Revista do Tribunal Regional Federal da $3^{\mathrm{a}}$ Região n ${ }^{\mathrm{o}}$. 75. São Paulo, 2006.

LEÃO, RENATO ZERBINI RIBEIRO. O reconhecimento dos refugiados pelo Brasil: Decisões comentadas do CONARE. CONARE e ACNUR Brasil. Servidéias, 2007. Disponível em: < http://www.corteidh.or.cr/tablas/24507.pdf> Acesso em: 17 nov. 2017.

LOESCHER, GIL. Beyond Charity: international cooperation and the global refugee crisis. New York: Oxford University Press, 1996.

MAURER, BEATRICE et al. Dimensões da Dignidade: Ensaios de Filosofia do Direito e Direito Constitucional (Org. Ingo Wolfgang Sarlet). Porto Alegre: Livraria do Advogado, 2005.

MAZZUOLI, VALÉRIO DE OLIVEIRA. Teoria geral do controle de convencionalidade no direito brasileiro. In: Revista Direito e Justiça: Reflexões Sociojurídicas, Ano IX, nº 12, mar. 2009.

MAZZUOLI, VALÉRIO DE OLIVEIRA. O controle jurisdicional de convencionalidade das leis, 3. ed. São Paulo: RT, 2013.

Ministério da Justiça. Diferenças entre refúgio e asilo. Disponível em: <http://www.justica.gov.br/noticias/entenda-as-diferencas-entre-refugio-e-asilo> acesso em: 11 set. 2017.

MOREIRA, JULIA BERTINO. Redemocratização e direitos humanos: a política para refugiados no Brasil Revista Brasileira de Política Internacional, v. 53, n. 1, jan./jul. 2010, p. 111-129. Instituto Brasileiro de Relações Internacionais Brasília, Brasil.

MOREIRA, JULIA BERTINO. Refugiados no Brasil: reflexões acerca do processo de integração social. Revista Interdisciplinar de Mobilidade Humana, n. 43. Brasília, 2014.

ONU. Declaração de Nova Iorque sobre Refugiados e Migrantes de 2016. Assembleia Geral da ONU. Disponível em: <http:/www.un.org/en/ga/search/view_doc.asp?symbol=A/RES/71/1> Acesso em: 28 out. 2017. 
PIOVESAN, FLÁVIA. Temas de Direitos Humanos, 5. ed. São Paulo: Saraiva, 2012.

PIOVESAN, FLÁVIA. Direitos Humanos e o Direito Constitucional Internacional, 16. ed. São Paulo: Saraiva, 2016.

RAMOS, ANDRÉ DE CARVALHO. Curso de Direitos Humanos, 4. ed. São Paulo: Saraiva, 2017.

RAMOS, ANDRÉ DE CARVAlHO. Teoria Geral dos Direitos Humanos na Ordem Internacional, 5. ed. São Paulo: Saraiva, 2015.

RAMOS, ANDRÉ DE CARVALHO, RODRIGUES, GILBERTO; ALMEIDA, GUILHERME ASSIS DE. 60 anos de ACNUR: perspectivas de futuro. São Paulo: CL-A Cultural, 2011.

ROCHA, ROSSANA REIS; MOREIRA, JULIA BERTINO. Regime internacional para refugiados: mudanças e desafios. Revista de Sociologia e Política, v. 18, n. 37, out. 2010, p. 17-30. Universidade Federal do Paraná Curitiba, Brasil.

SARLET, INGO. Dignidade da pessoa humana e direitos fundamentais na Constituição Federal de 1988. Porto Alegre: Livraria do Advogado, 2011.

SILVA, CÉSAR AUGUSTO S. DA; MORAES, THAYS DE MELLO. A política migratória brasileira para refugiados e a imigração haitiana. Revista do Direito. Santa Cruz do Sul, v. 3, n. 50, p. 98-117, set./dez. 2016.

ZOLBERG, ARISTIDE. Matters of State: theorizing immigration policy. In: HIRSCHMAN, CHARLES; KASINITZ, PHILIP; DEWIND, JOSH (Org.). The handbook of international migration: the American experience. New York: Russell Sage foundation, 1999.

\section{DADOS DOS AUTORES}

\section{Maria Angélica Chichera}

Doutoranda em Direito pela Pontifícia Universidade Católica de São Paulo - PUC-SP. Mestre em Direito pela Universidade Nove de Julho. Advogada e docente. gelichichera@ yahoo.com.br

\section{Ricardo GLASENAPP}

Doutor em Direito Constitucional pela PUC-SP. Mestre em Direito Constitucional pela PUC-SP. Especialista em Direito Constitucional pela ESDC - Escola Superior de Direito Constitucional. Graduado pela Faculdade de Direito de São Bernardo do Campo. ricardoglasenapp@hotmail.com

Submetido em: 7-10-2020

Aceito em: 20-10-2020 